\title{
Study of an Ozone Composing Mechanism derived from the Third Element on Surface of Electrode using Oxygen Gas: Part 2
}

\author{
Akira Murai Member (Kansai Electric Power Co., murai.akira@e3.kepko.co.jp) \\ Tsuyoshi Nakajima Non-member (Shinshu University)
}

Keywords: electric discharge, ozone, surface of anode, simulation, antimony

The ozone composing mechanism had not been examined experimentally in both the electrical discharge stage and the ozone composing stage separately. It was, therefore, impossible to determine exactly how ozone was composed and, as a result of this, to get high yield efficiency in producing ozone. In examining the ozone composing mechanism we conducted four experiments. In part 2 , we explain the final two experiments.

In our third experiment, we changed the density of nitrogen by adding heat energy to the anode. Consequently, we concluded that ozone required a third element (like nitrogen) at the surface of the anode when composing ozone as shown in Fig. 1. For the purposes of our experiment we assumed a constant rate of temperature alternation between $30\left[{ }^{\circ} \mathrm{C}\right]$ and $45\left[{ }^{\circ} \mathrm{C}\right]$. This is shown in the 'saw tooth' pattern in Fig. 2. The density of nitrogen on the surface of the anode was presumed to increase $1.8\left[\% /{ }^{\circ} \mathrm{C}\right]$ when the temperature rose, and decrease $5.1\left[\% /{ }^{\circ} \mathrm{C}\right]$ when the temperature fell. A computer simulation confirmed the same phenomenon (Fig. 2). Then the copper anode was replaced with an antimony anode. We found that antimony worked better than nitrogen as a third element.

Finally, in the fourth experiment, we used an industrial ozone generator including ceramic dielectrics and a titanium expanded metal electrode. A decrease in the temperature of the cooling water led to a proportional increase in ozone. It follows the formula of van't Hoff as shown following equation:

$$
\log _{\mathrm{e}} \mathrm{K}=-\mathrm{dH} /(\mathrm{RT})+\mathrm{C}
$$

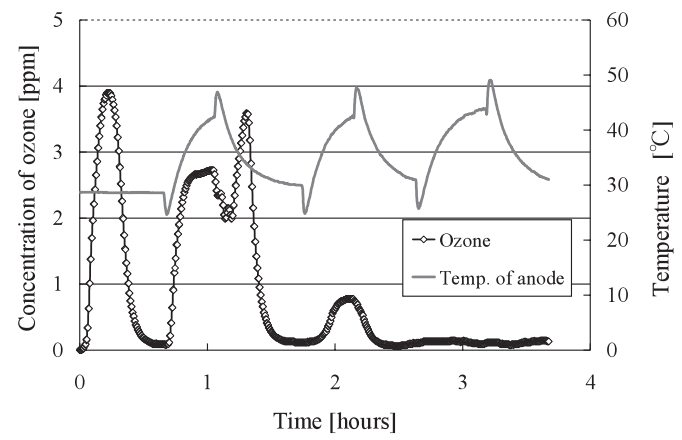

Fig. 1. Characteristic of alternations in a concentration of ozone (Exposure of nitrogen for 72 hours)
After spattering the surface of the electrodes with argon gas and supplying the ozone generator with $99 \%$ oxygen, we were able to produce ozone which was more than $20 \%$ higher in concentration than primary state ozone under the same conditions. The ozone generator produced ozone in high yield efficiency due to the optimum density of a third element like nitrogen on the surface of the electrodes. Antimony works better than nitrogen as a third element as shown in Fig. 3.

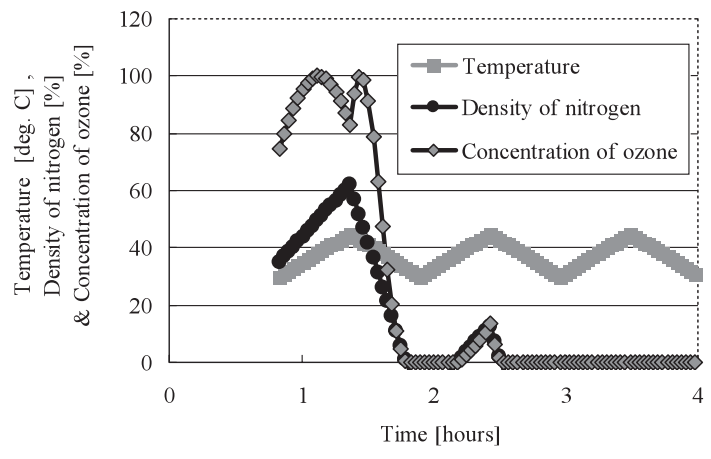

Fig. 2. Simulation (72 hours exposed)

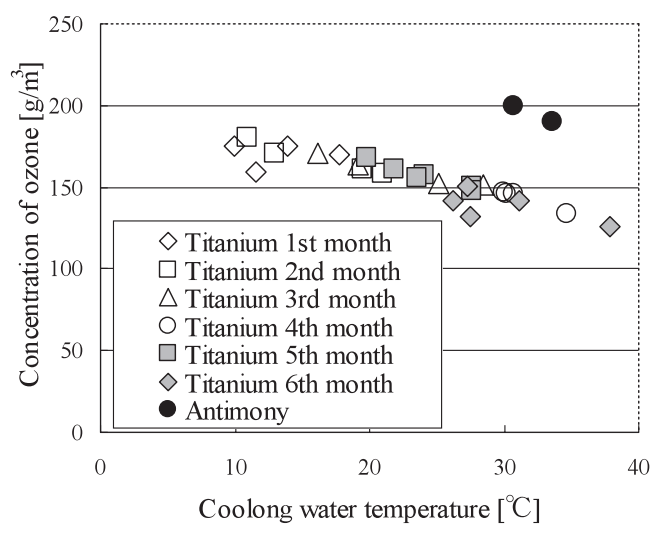

Fig. 3. Comparison of ozone concentration between nitrogen and antimony 


\title{
電極表面上の第三物質による酸素ガス中 オゾン生成反応の一考察（その2）
}

\author{
正 員 村井 昭* 非会員 中島 剛**

\section{Study of an Ozone Composing Mechanism derived from the Third Element on Surface of Electrode using Oxygen Gas: Part 2}

Akira Murai*, Member, Tsuyoshi Nakajima**, Non-member

In our third experiment, we changed the density of nitrogen through the addition of heat energy to the anode. A computer simulation confirmed the same phenomenon. Then the copper anode was replaced with an antimony anode. We found that antimony worked better than nitrogen as a third element.

Finally, in the fourth experiment, we used an industrial ozone generator including ceramic dielectrics and a titanium expanded metal electrode. A decrease in the temperature of the cooling water led to a proportional increase in ozone. It follows the formula of van't Hoff. After spattering the surface of the electrodes with argon gas and supplying the ozone generator with $99 \%$ oxygen, we were able to produce ozone which was more than $20 \%$ higher in concentration than primary state ozone under the same conditions. The ozone generator produced ozone in high yield efficiency due to the optimum density of a third element like nitrogen on the surface of the electrodes. Antimony works better than nitrogen does as a third element.

キーワード : 電気放電, オゾン, 電極表面反応, シミュレーション, アンチモン

Keywords: electric discharge, ozone, surface of anode, simulation, antimony

\section{1. まえがき}

近年，水環境に対する人々の関心が高くなってきている。 関西地域では既に上水道のオゾン処理が広く行われており, 下水処理水に対するオゾン処理の時代を迎えようとしてい る。オゾンはエネルギー多消費型の原材料物質であり，製 造コストの高さがオゾン処理の普及を阻害している。オゾ ンを効率良く製造するため酸素ガスを用い実験を繰り返し てきた結果，99.5\%酸素ガス中での電気放電においてオゾ ン生成反応は進まないが, 窒素を銅電極表面に吸着させる ことにより，電極表面で効率良くオゾンが生成されること が確認できた ${ }^{(1) \sim(5) 。 ~}$

電極表面の第三物質の密度を仮定したシミュレーション が実験の特性を良く反映しており，99.999\%酸素を用いた 窒素族系のアンチモン蒸着電極による計測では 1.5 倍以上

\footnotetext{
* 関西電力 (株)

干 619-0237 京都府相楽郡精華町光台 1-7 けいはんなプラザ

The Kansai Electric Power Co. Inc.

1-7, Hikaridai, Seikacho, Sourakugun, Kyoto 619-0237

** 信州大学

干 380-8553 長野市若里 4 丁目 17 番 1 号

Shinshu University

4-17-1, Wakasato, Nagano 380-8553
}

のオゾン生成効果が確認できた。99\%酸素を用いた商用機 においても第三物質密度の最適化による効率向上とアンチ モンによるオゾン生成効率向上効果が確認できたので報告 する。

\section{2. 実験装置の構成}

純酸素ガス中での電気放電においてオゾン濃度の変化と して, 放電開始直後にオゾンが生成され, その後, オゾン 濃度 0 になる現象が見られた。これは実験の初期段階にお いて, 実験開始前に放電部に付着した窒素によりオゾンが 発生し, 放電の継続により当該部分の窒素がなくなったた めオゾンが発生しなくなったと考えられる。このことから 銅表面でのオゾン生成反応を持続的に発現させる方法（言 い換えれば銅電極表面の窒素密度を増加させる方法）とし て電極加熱を検討し実験を行った。

実験装置の概要を図 1 に示す。各構成機器は, 図 1 の左 から順次以下に記載するとおりである。

1）酸素ガスボンベ

2）ガス流量制御装置

3）加熱制御装置

4) イオン化高電圧源

5）イオン化室 


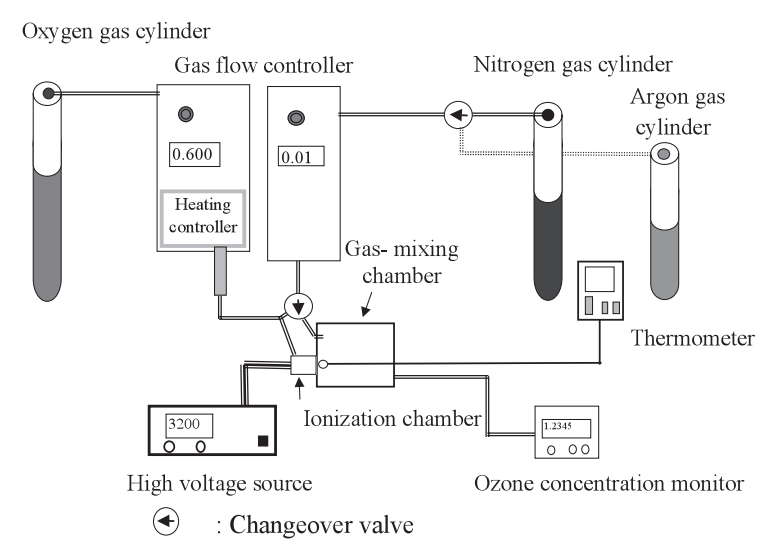

図 1 実験装置概要図

Fig. 1. Experiment device outline.

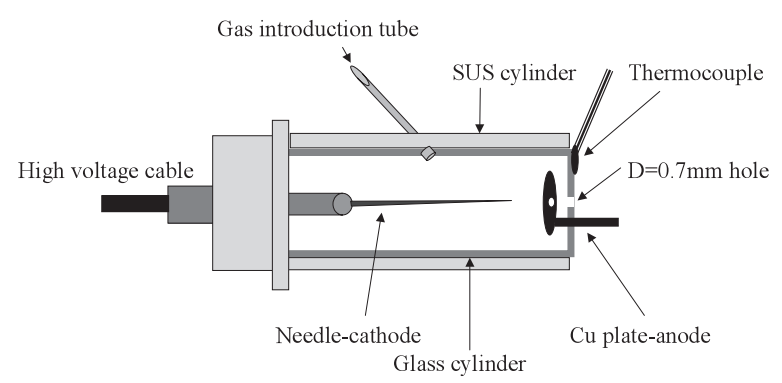

図2 イオン化室断面図

Fig. 2. Ionization chamber cross section.

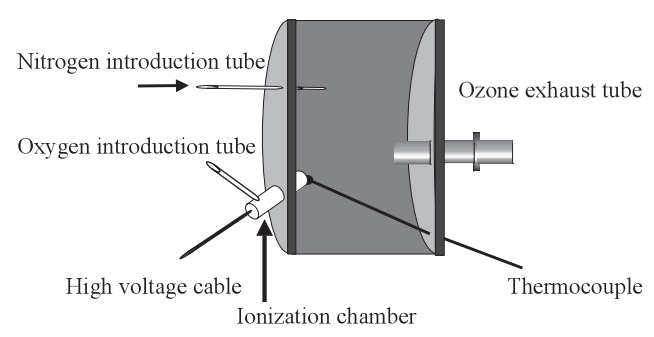

図 3 ガス混合室断面図

Fig. 3. Gas-mixing chamber cross section.

・電極配置等を図 2 に示す。

6）ガス混合室

・各配管の配置図を図 3 に示す。

7）窒素ガスボンベ

8) 温度計

9) オゾン濃度計

\section{3. 電極表面でのオゾン生成}

〈3・1〉 電極加熱による効果電極表面の窒素密度を 上昇させるため， $1 \mathrm{~kW}$ のドライヤーによりイオン化室を 加熱した。加熱放熱を繰り返した時のオゾン濃度の変化を 図 4 に示す。ここで 5 回目の加熱時においてオゾン濃度の 上昇が見られないのは，電極表面の窒素密度がオゾンを生 成するのに必要な濃度に達しなかったためと考えられる。 この実験条件は，電極間距離 $3 \mathrm{~mm}, 99.5 \%$ 酸素ガス流量 $400 \mathrm{ml} / \mathrm{min}$, 放電電流 $1 \mu \mathrm{A}$ とした。課電電圧は, 3,100

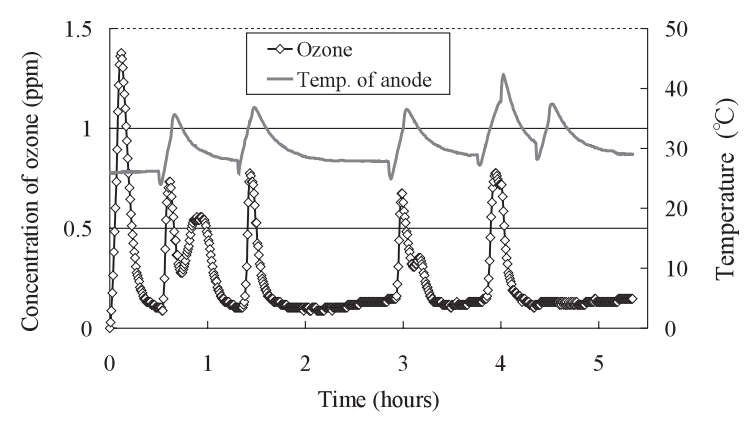

図 4 加熱放熱によるオゾン濃度の変化

Fig. 4. Fluctuation in the concentration of ozone due to a repetition of the heating cycle.

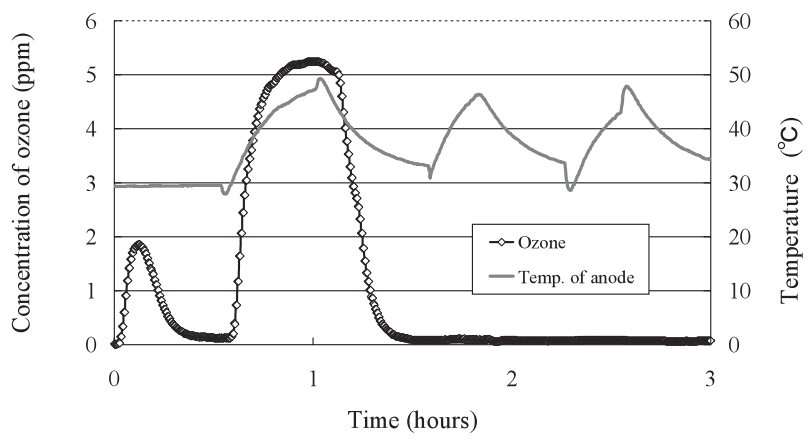

図 5 オゾン濃度の変化（窒素暴露 24 時間）

Fig. 5. Characteristic of alternations in a concentration of ozone (Exposure of nitrogen for 24 hours).

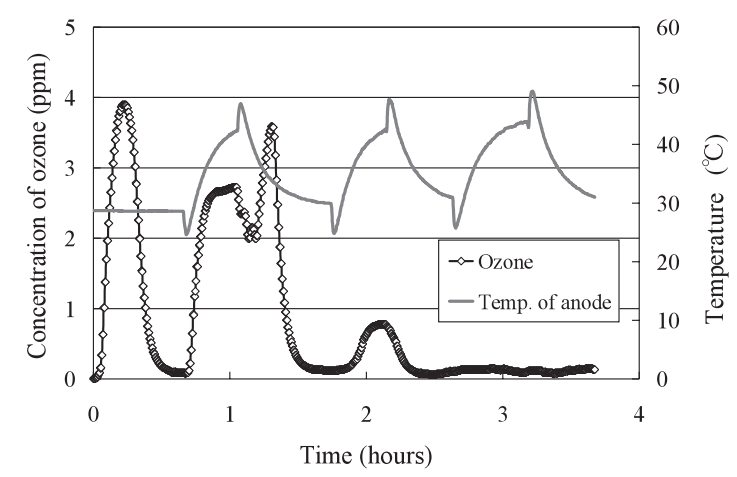

図 6 オゾン濃度の変化（窒素暴露 72 時間）

Fig. 6. Characteristic of alternations in a concentration of ozone (Exposure of nitrogen for 72 hours).

$4,000 \mathrm{~V}$ の範囲で変化した。

$\langle\mathbf{3} \cdot \mathbf{2}\rangle$ 窒素暴露 24 時間 $\langle 3 \cdot 1\rangle$ 節の実験後, 窒素ガ スを流し 24 時間放置した。次に同一条件で放電を行った。 この時のオゾン濃度の変化を図 5 に示す。

オゾン濃度の変化としては, 最初 $1.86 \mathrm{ppm}$ まで上昇し その後急激に低下した。その後，イオン化室を加熱すると $5.25 \mathrm{ppm}$ まで上昇しその状態が長く続いた。2 回目以降で はオゾン濃度の変化は見られなかった。

$\langle\mathbf{3} \cdot \mathbf{3}\rangle$ 窒素暴露 72 時間 $\langle 3 \cdot 2\rangle$ 節の実験後, 窒素ガ スを流し 72 時間放置した。次にく3.2〉節同様に同一条件 で放電を行った。この時のオゾン濃度の変化を図 6 に示す。 
オゾン濃度の変化としては, 前 2 回同様, 最初 $3.90 \mathrm{ppm}$ まで上昇しその後急激に低下した。その後，イオン化室を 加熱すると $2.73 \mathrm{ppm}$ まで上昇したが，冷却時に二瘤らくだ 状態になり $3.59 \mathrm{ppm}$ までオゾン濃度が上昇した。2 回目の 加熱では $0.78 \mathrm{ppm}$ までオゾン濃度が上昇したが，3 回目で はオゾン濃度の変化は見られなかった。

\section{4. オゾン濃度変化のシミュレーション}

窒素暴露後の加熱冷却過程のオゾン濃度をシミュレーショ ンすることとし，電極表面において窒素が第三物質として 働く場合，吸着分子は運動エネルギーをほとんど持たない ため 3 体衝突は電極に吸着した酸素分子と窒素分子の境界 近くに酸素原子が衝突した時に発生し，三体衝突の確率分 布は (1) 式（図 7) に示す正規分布に従うと考えた。

$\mathrm{f}(\mathrm{x})=\frac{1}{\sigma \sqrt{2 \pi}} \exp \frac{-(\mathrm{x}-\mu)^{2}}{2 \sigma^{2}}-\mathrm{C}$

ここで $\mathrm{x}$ :第三物質密度, $\sigma$ : 分散, $\mu$ :母平均 $(0.5)$,

$\mathrm{C}$ : 第三物質密度 0 および 1 において分布曲線を

0 に一致させるための定数である。

温度変化は単純化するため三角波状に $30^{\circ} \mathrm{C} \sim 45^{\circ} \mathrm{C}$ の間 において一定割合で変化するものとし, 実験結果 (傾向)を

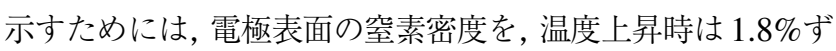

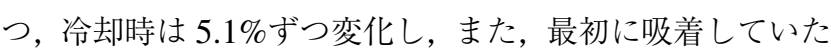
窒素密度として表 1 に示す数值を採用すれば傾向がよく一 致する。ここで, 窒素が放電により脱着する現象を考慮し

温度冷却時变化率 $>$ 温度上昇時変化率

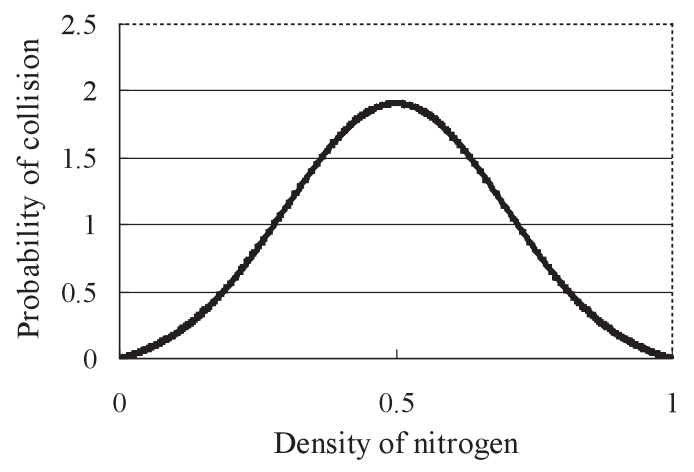

図 7 窒素密度と三体衝突の確率分布

Fig. 7. Probability of collision between oxygen atom and oxygen molecule which is adjacent to a nitrogen molecule.

表 1 シミュレーション用諸元

Table 1. Coefficient for simulation.

\begin{tabular}{|c|c|c|}
\hline & 24 hours & 72 hours \\
\hline Initial density $(\%)$ & 25 & 35 \\
\hline Ratio of rise $\left(\% /{ }^{\circ} \mathrm{C}\right)$ & 1.8 & 1.8 \\
\hline Ratio of fall $\left(\% /{ }^{\circ} \mathrm{C}\right)$ & 5.1 & 5.1 \\
\hline
\end{tabular}

初期窒素密度は窒素暴露時間に対し $1-\exp (-\mathrm{t})$ の関数に従 い増加するものとした。

このオゾン濃度の計算を数式化すると, 時間的な温度変 化 $\mathrm{T}(\mathrm{t})$ は,

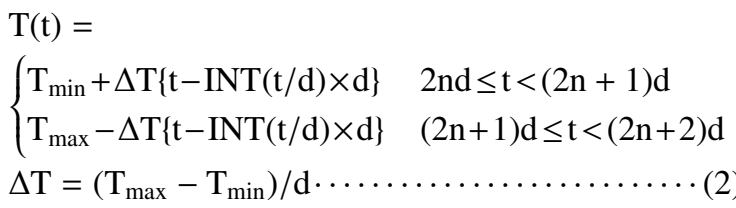

ここで, $\mathrm{T}_{\max }$ : 最高温度, $\mathrm{T}_{\min }$ : 最低温度, $\mathrm{d}$ : 温度 変化 $1 / 2$ サイクルの分割数, $\mathrm{n}: 0,1,2, \cdots, \operatorname{INT}()$ : () 内の数值をその数值よりゼロに近い整数に丸め る。 $\mathrm{T}$ ：単位時間あたりの温度変化。

で与えられる。

一方，表面窒素密度関数 D(t) と温度との関係は,

$\mathrm{D}(\mathrm{t}+1)-\mathrm{D}(\mathrm{t})=\{\mathrm{T}(\mathrm{t}+1)-\mathrm{T}(\mathrm{t})\} \times \mathrm{I}\{\mathrm{T}(\mathrm{t}+1)-\mathrm{T}(\mathrm{t})\}$

ここで関数 $\mathrm{I}$ および表面窒素密度関数の初期值 $\mathrm{D}_{0}$ は

$$
\begin{aligned}
& \mathrm{I}\{\mathrm{T}(\mathrm{t}+1)-\mathrm{T}(\mathrm{t})>0\}=\mathrm{a} \quad \mathrm{a}, \mathrm{b}: \text { 正整数 } \\
& \mathrm{I}\{\mathrm{T}(\mathrm{t}+1)-\mathrm{T}(\mathrm{t})<0\}=-\mathrm{b} \\
& \mathrm{D}(0)=\mathrm{D}_{0} \ldots \ldots \ldots \ldots \ldots \ldots \ldots \ldots \ldots \ldots \ldots \ldots
\end{aligned}
$$

で与えられる。

表面窒素密度関数の時間的変化 D(t) は,

$$
\begin{aligned}
& D(t)= \\
& \begin{cases}D_{m}+a\{t-I N T(t / d) \times d\} & 2 n d \leq t<(2 n+1) d, m: \text { 奇数 } \\
D_{m}-b\{t-I N T(t / d) \times d\} & (2 n+1) d \leq t<(2 n+2) d, \\
& m: \text { 偶数 }\end{cases}
\end{aligned}
$$

ここで, $\mathrm{D}_{\mathrm{m}}$ は，

$$
\mathrm{D}_{\mathrm{m}}=\mathrm{D}_{0}+\{\mathrm{a} \operatorname{INT}(\mathrm{m} / 2)-\mathrm{b} \operatorname{INT}(\mathrm{m} / 2-1 / 2)\} \mathrm{d}
$$

これより，電極表面窒素密度 $\mathrm{D}_{\mathrm{a}}(\mathrm{t})$ は，

$$
D_{a}(t)= \begin{cases}D(t) & D(t) \geq 0 \\ 0 & D(t)<0\end{cases}
$$

で与えられる。

オゾン濃度の变化 $\mathrm{C}(\mathrm{t})$ は, 窒素密度により変化する関数 $\mathrm{Y}(\mathrm{t})$ を用い,

$$
\begin{aligned}
& \mathrm{Y}(\mathrm{t})=\mathrm{f}\left(\mathrm{D}_{\mathrm{a}}(\mathrm{t})\right) \\
& \mathrm{C}(\mathrm{t})=\left\{\begin{array}{ll}
\mathrm{Y}(\mathrm{t}) & \mathrm{Y}(\mathrm{t}) \geq 0 \\
0 & \mathrm{Y}(\mathrm{t})<0
\end{array} .\right.
\end{aligned}
$$

で表される。 


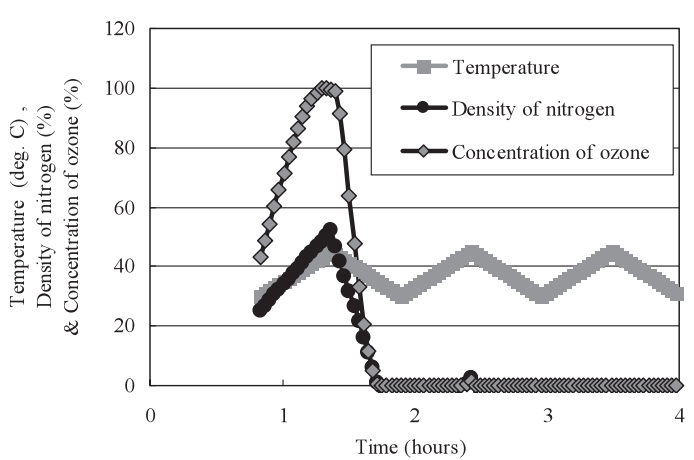

図 8 シミュレーション 1（窒素暴露 24 時間）

Fig. 8. Simulation 1 (24 hours exposed).

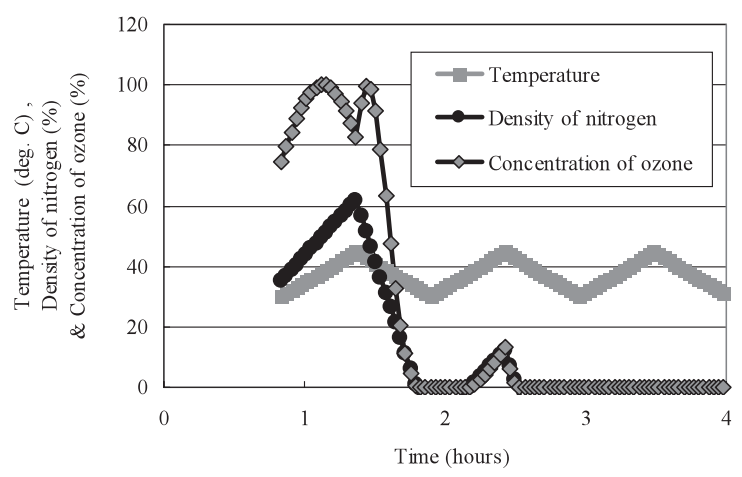

図 9 シミュレーション（窒素暴露 72 時間）

Fig. 9. Simulation 2 (72 hours exposed).

〈4·1〉 シミュレーション 1 (窒素暴露 24 時間) 最初 の電極表面窒素の密度を $25 \%$ としてシミュレーションした ものを図 8 に示す。このグラフから最初の加熱によりオン゙ ン濃度が上昇した後，少しの間高い濃度を保ちその後減少 している様子，および 2 回目以降の加熱によりオゾンが発 生していない様子が再現できている。

〈4·2〉 シミュレーション（窒素暴露 72 時間）最初 の電極表面窒素の密度を $35 \%$ としてシミュレーションした ものを図 9 に示す。このグラフから最初の加熱によりオゾ ン濃度が上昇した後，少しの間高い濃度を保ちその冷却時 再度オゾン濃度が上昇し二瘤らくだ状になる様子，そして 2 回目の加熱によりオゾン生成が発生する様子が再現でき ている。

\section{5. アンチモンによる効果の確認}

実験において放電状態を目視するため, 図 10, 図 11 に示 すようにイオン化室の電極側を透明アクリル製としガス混 合室を無くした。この平板電極部分を釬状銅電極とし表 2 に示すように銅およびアンチモンを真空蒸着した。

$400 \mathrm{ml} / \mathrm{min}$ の $99.999 \%$ 酸素ガスを供給し， $1 \mu \mathrm{A}$ の定電 流により得られた結果を図 12 に示す。アンチモンを蒸着 した銅（0-8 時間のデータ）と比較して 1.5 倍にオゾン濃 度が上昇した。これにより窒素族系のアンチモンの効果が 確認できた。
$99.999 \%$

Oxygen gas cylinder

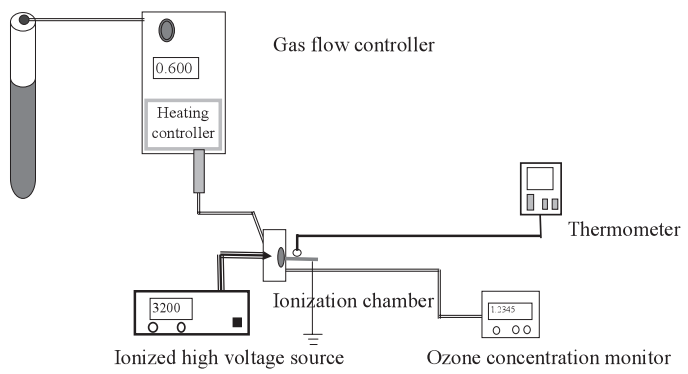

図 10 実験装置概要図 2

Fig. 10. Experiment device outline of equipment 2.

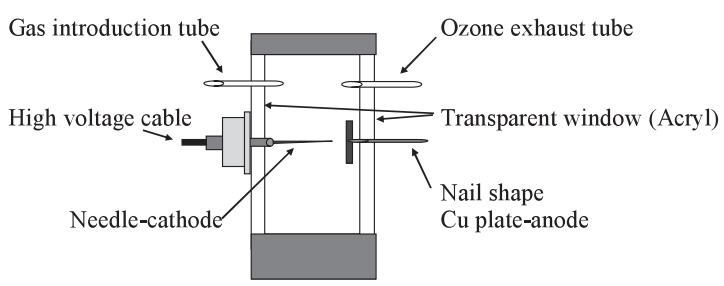

図 11 アクリル製イオン化室断面図 2

Fig. 11. Ionization chamber cross section2 (acryl).

表 2 真空蒸着諸元

Table 2. Conditions of evaporation coating.

\begin{tabular}{|c|c|c|c|c|}
\hline \multirow{2}{*}{ No } & \multirow{2}{*}{ Copper (base) } & \multicolumn{2}{|c|}{ Antimony } & \multirow{2}{*}{ Time (sec) } \\
& & Thickness (nm) & Copper (cover) \\
\hline 1 & $10 \min 0.5 \mu \mathrm{m}$ & 0 & 0 & 0 \\
\hline 2 & $10 \mathrm{~min} 0.5 \mu \mathrm{m}$ & 1 & 2.2 & $30 \sec 27 \mathrm{~nm}$ \\
\hline 3 & $10 \mathrm{~min} 0.5 \mu \mathrm{m}$ & 32 & 70 & $30 \sec 27 \mathrm{~nm}$ \\
\hline
\end{tabular}

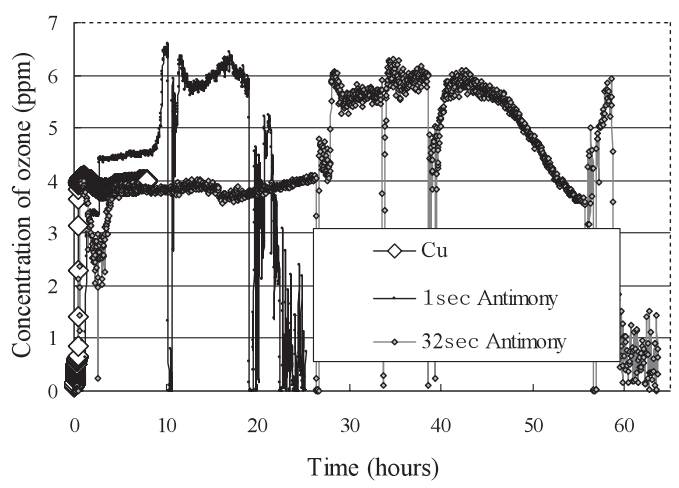

図 12 銅とアンチモン電極の比較

Fig. 12. Comparison of ozone concentration between copper and antimony.

\section{6. 商用オゾン発生器の概要と特性}

誘電体電極とチタン製のエキスパンドメタル電極を有す る商用機で表面窒素濃度によるオゾン生成効率の变化を確 認した。このオゾン発生器の発生能力は $10 \mathrm{~g} / \mathrm{h}$ で投入電力 は $100 \mathrm{~W}$ である。外観は幅 $19 \mathrm{~cm}$, 高さ $43 \mathrm{~cm}$, 厚さ約 $5 \mathrm{~cm}$ の直方体であり, 長辺 $94 \mathrm{~mm}$, 短辺 $83 \mathrm{~mm}$, 高さ $177 \mathrm{~mm}$ の台形型エキスパンドメタル電極を, 厚さ $1 \mathrm{~mm}$ のセラミッ 


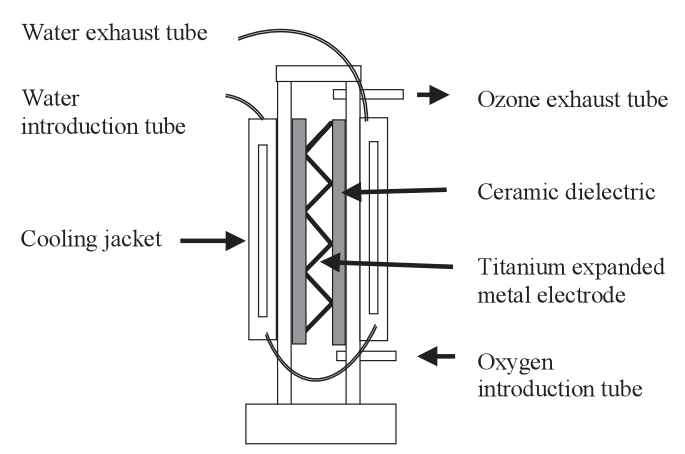

図 13 オゾン発生器断面図

Fig. 13. Cross section of the experimental device.

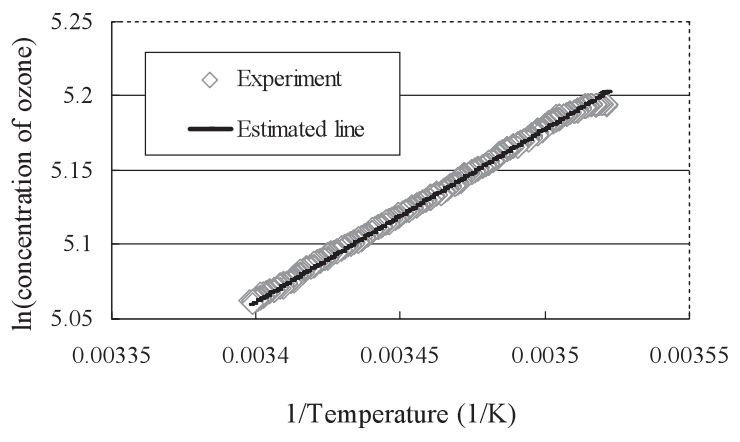

図 14 冷却水温度の变化に伴うオゾン濃度変化

Fig. 14. Characteristic of ozone concentration due to changing cooling water temperature.

ク誘電体で挟んだ形で設置した。本体を接地（アース）電 極として使用している。この構造を図 13 に示す。

オゾン濃度に関して冷却水温度（電極温度）を変化させ て計測するとその結果は図 14 に示す様に直線になる。こ の結果オゾン生成量は (10) 式に示すようにファント・ホッ フの式(の)に従い安定していることが分かる。

$\log _{\mathrm{e}} \mathrm{K}=-\Delta \mathrm{H} /(\mathrm{RT})+\mathrm{C}$

ここで, $\mathrm{K}$ : 圧力平衡定数, $\mathrm{H}$ : エンタルピー $[\mathrm{J} / \mathrm{mol}]$,

$\mathrm{R}$ : 気体定数 $[\mathrm{J} /(\mathrm{mol} \cdot \mathrm{K})], \mathrm{T}$ : 温度 $[\mathrm{K}], \mathrm{C}$ : 定数 である。

エンタルピーの変化量は, $10 \mathrm{~kJ} / \mathrm{mol}$ 程度であり, 酸素の 蒸発熱 $6.82 \mathrm{~kJ} / \mathrm{mol}$ に近い值となっている。よって, 電極表 面の吸着酸素の脱離がオゾン生成に密接な関係を持つと考 えられる。

このオゾン発生器において, 直径 $6 \mathrm{~mm}$ のチューブを介 して大気に開放し，アルゴンで置換後，流量 $5 \mathrm{ml} / \mathrm{min}$ の アルゴンガスを流しながら $100 \mathrm{~W}$ で 55 分間スパッタリン グした。その後，99\%酸素ガスを流しオゾンを生成した結 果を図 15 に示す。オゾン濃度は徐々に上昇し, 初期值の $98 \mathrm{~g} / \mathrm{m}^{3}$ から $120 \mathrm{~g} / \mathrm{m}^{3}$ に達した。その後, オゾン濃度は急 激に低下し 0 になった。これは図 7 に示す窒素密度 0.5 以 上の密度からスパッタリング効果により減少し最終的には 0 になる現象と考えられる。このことから，電極表面の第

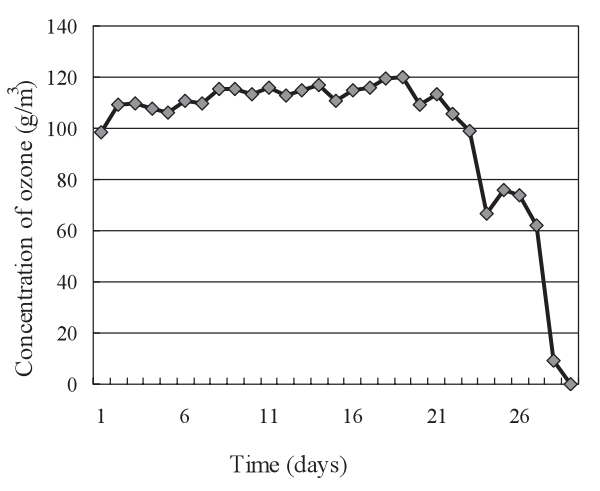

図 15 オゾン濃度の長期変化

Fig. 15. Changes in the concentration of ozone under the same conditions.

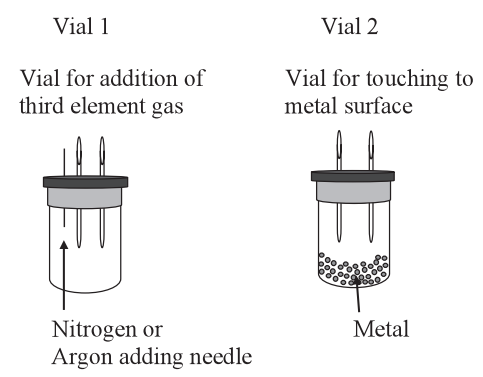

困 16 接触器具の概要

Fig. 16. Vials for touching.

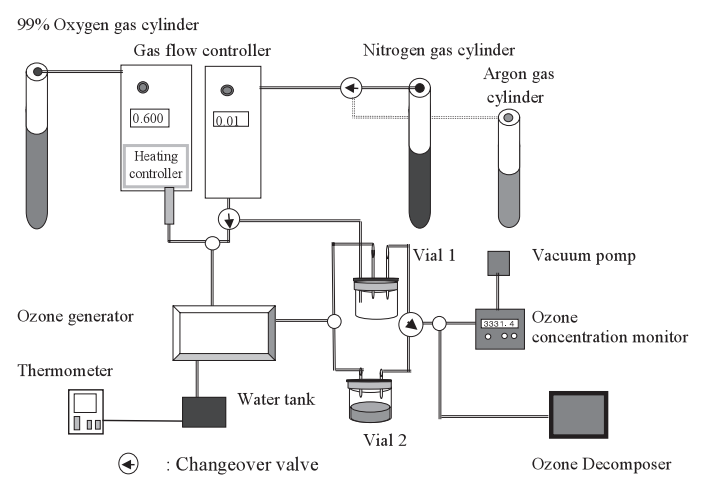

図 17 接触器具の挿入図

Fig. 17. Experiment device outline of equipment 3.

三物質（今回の実験は長期間空気に暴露されていた放電体 を使用して抢り，第三物質としての窒素の減少過程を記録 していると考えている。）の濃度を最適化することによりオ ゾン生成効率を増加させられることが判明した。

\section{7. 放電後の酸素ガスの希ガス・触媒金属との接触}

長期間オゾンを生成し，オゾン濃度が低下した時に生産 されたオゾンガスを希ガス及び触媒金属に接触させた。接 触方法としては, オゾン発生器とオゾン濃度計の間に図 16 に示すガス接触と金属接触用の接触器具を図 17 に示すよ うに挿入した。

オゾン濃度が高い時のガス添加及び触媒金属に接触させ 


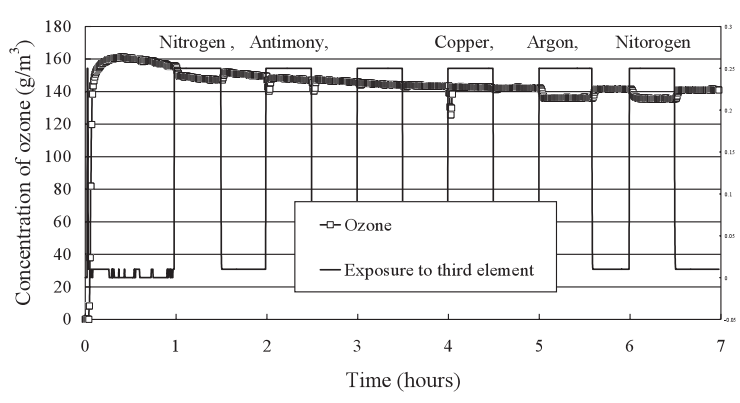

図 18 オゾン濃度が高い場合の接触

Fig. 18. Change in ozone concentration during ozone generator in normal condition.

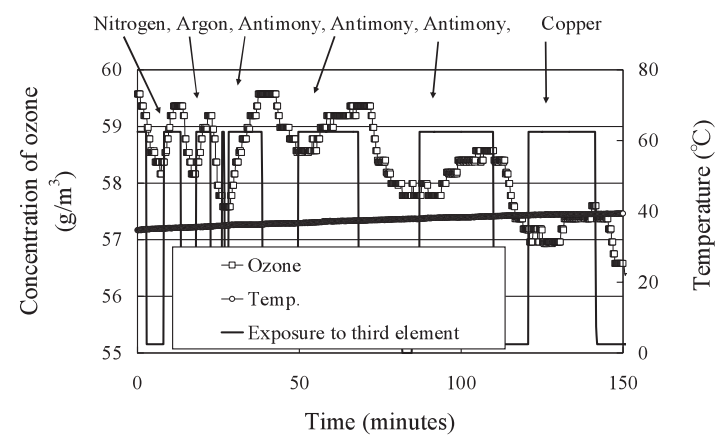

図 19 オゾン濃度が低下した場合の接触

Fig. 19. Change in ozone concentration during ozone generator become low concentration.

た結果を図 18 に示す。なお，ガス添加および金属への接 触以外の時間帯は，オゾンガスをVial1に通し添加ガスを 加えない状態である。このとき，ガス添加によりオゾンが 希釈されオゾン濃度が低下し，また，金属接触に関しては 変化がなかった。

オゾン濃度が低下した時のガス添加及び触媒金属に接触 させた結果を図 19 に示す。このとき，窒素ガス，アルゴ ンガスのどちらのガス添加によっても接触器具内において オゾンが生成されオゾン濃度が上昇した。また，アンチモ ン，銅のどちらの金属接触によってもオゾン濃度が上昇し た。ただし，銅による場合は濃度上昇が少ない。また，ガ スを切り替えてから少し時間差を持って上昇に転じている ことから銅金属の表面に吸着した窒素がオゾンを生成して いると考えられる。

\section{8. アンチモン電極への変更}

商用オゾン発生器の電極をアンチモン化するため, チ夕 ン電極に真空蒸着を施した。この電極により得られた結果 を過去のチタン電極と比較し図 20, 図 21 に示す。アンチ モンを蒸着した電極によりチタン電極より多くのオゾンが 生成されることが判明した。特に図 21 から同一オゾン濃 度を発生させるのに 2 倍の酸素流量が可能であり生成効率 が 2 倍になったことが分かる。

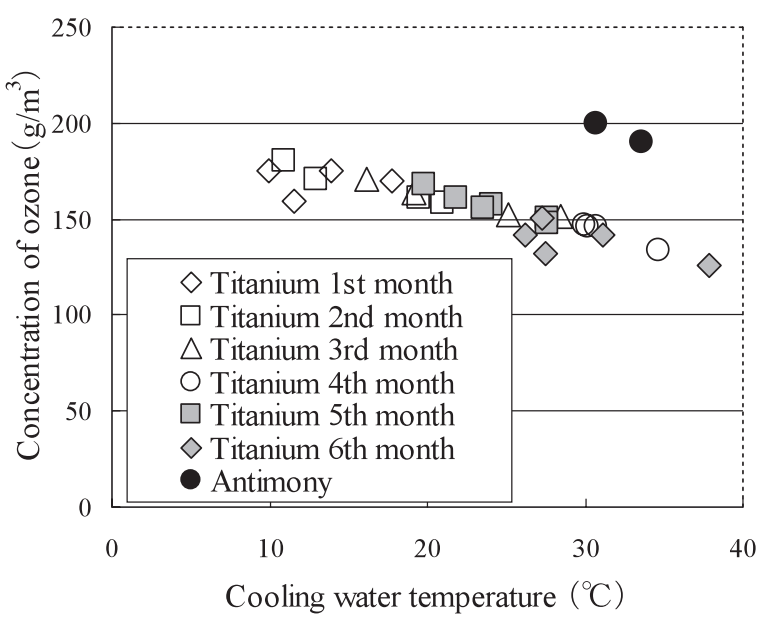

図 20 チタンーアンチモン比較（酸素流量 $0.5 \mathrm{l} / \mathrm{min}$ )

Fig. 20. Comparison of ozone concentration between nitrogen and antimony at same flow rate.

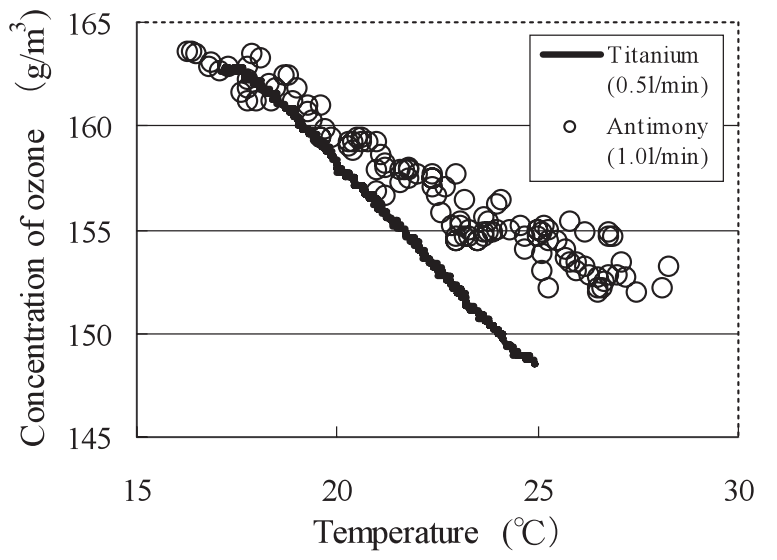

図 21 チタンーアンチモン比較（酸素流量； $0.51 / \mathrm{min}: 1.01 / \mathrm{min})$

Fig. 21. Comparison of ozone concentration between nitrogen and antimony at same temperature.

\section{9. まとめ}

電極表面に付着した窒素を第三物質としてオゾン生成反 応が進行することを確認した。また，この電極表面の窒素 密度を適正化することによりオゾン収率が向上することを 確認し，コンピュータ・シミュレーションによりそのメカ ニズムの解析を試みた。電極表面の第三物質の密度を仮定 したシミュレーションが実験の特性を良く反映しており， この第三物質の効果は単にアルゴンなどの希ガス, 窒素等 だけではなく窒素族系の金属にもこの効果があると考えア ンチモンを見出した。99.999\%酸素を用いた窒素族系のア ンチモン蒸着電極による計測では 1.5 倍以上のオゾン生成 効果が確認できた。99\%酸素を用いた商用機においても第 三物質密度の最適化による効率向上とアンチモンによるオ ゾン生成効率向上効果が確認できた。これまでのオゾンは 電気放電部でのみ生成されるべきであるという常識的な概 
念が覆され, 多くの科学者がこの新しい分野の研究に参加 されることを期待する。

(平成 17 年 7 月 11 日受付, 平成 18 年 7 月 28 日再受付)

\section{文献}

（1）村井 昭・田原德夫：「オゾン発生メカニズムの解析」, 平 16 電学全 大, pp.IV-265-266 (2004)

（2）村井 昭 - 田原德夫： "Analysis of Ozone Composing Mechanism due to Development of Ozone Generator", 電気工学技術国際会議（ICEE2004 札幌大会), Proceeding, pp.730-735 (2004)

（3）村井 昭・田原徳夫・中島 剛：「酸素ガス中電気放電と電極表面 上の第三物質によるオゾン生成反応」, 電学基礎・材料・共通部門大 会講演論文集, pp.254-259 (2004)

（4）村井 昭・田原徳夫・中島 剛:「オゾン発生器開発のための生成 メカニズムの予備的検討」, エネルギー・資源学会誌, Vol.26, No.1, pp.58-64 (2005)

（5）村井 昭・田原徳夫・中島 剛：「金属触媒によるオゾン生成法の 考察」, 平 17 電学全大, pp.IV-305-306 (2005)

（6） 中村義男：「化学熱力学の基礎」, 三共出版, pp.131-144 (1995)
村 井

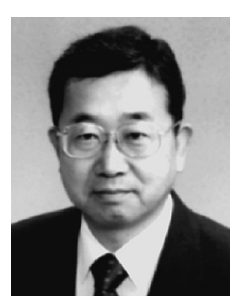

昭（正員） 1950 年生。1974 年信州大学工学部電気 工学科卒業。同年関西電力 (株) 入社。1997 年 同社総合技術研究所を経て, 電力技術研究所勤務。 主として, 電気利用技術 (オゾン) の研究に従事。 現在, 同社環境技術研究センター主席研究員。博 士 (工学)。電気設備学会, 日本オゾン協会, 国 際オゾン協会各会員。

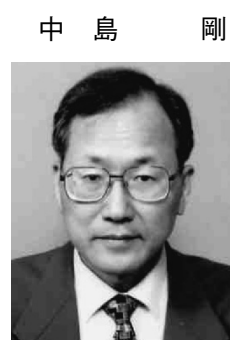

剛（非会員）1941 年生。1967 年北海道大学大学院 理学研究科修士課程修了。1999 年信州大学教授, 現在に至る。主として, 触媒に関する研究に従事。 理学博士。日本化学会, エネルギー・資源学会, 触媒学会, 日本表面科学会, 化学ソフトウェア学 会, 電気化学会, 日本オゾン協会, 国際オゾン協 会各会員。 